$\eta$

5101-161

Low-Cost

Solar Array Project

\title{
Block V Solar Cell Module: Design and Test Specification for Intermediate-Load Applications, ₹ 1981
}

LSA Engineering Area

\section{AIOI-16CS3/037}

February 20, 1981

Prepared for

U.S. Department of Energy

Through an agreement with

National Aeronautics and Space Administration

by

Jet Propulsion Laboratory

California Institute of Technology

Pasadena, California 


\section{DISCLAIMER}

This report was prepared as an account of work sponsored by an agency of the United States Government. Neither the United States Government nor any agency Thereof, nor any of their employees, makes any warranty, express or implied, or assumes any legal liability or responsibility for the accuracy, completeness, or usefulness of any information, apparatus, product, or process disclosed, or represents that its use would not infringe privately owned rights. Reference herein to any specific commercial product, process, or service by trade name, trademark, manufacturer, or otherwise does not necessarily constitute or imply its endorsement, recommendation, or favoring by the United States Government or any agency thereof. The views and opinions of authors expressed herein do not necessarily state or reflect those of the United States Government or any agency thereof. 


\section{DISCLAIMER}

Portions of this document may be illegible in electronic image products. Images are produced from the best available original document. 


\title{
Block V Solar Cell Module: Design and Test Specification for Intermediate-Load Applications, ₹- 1981
}

\author{
LSA Engineering Area
}

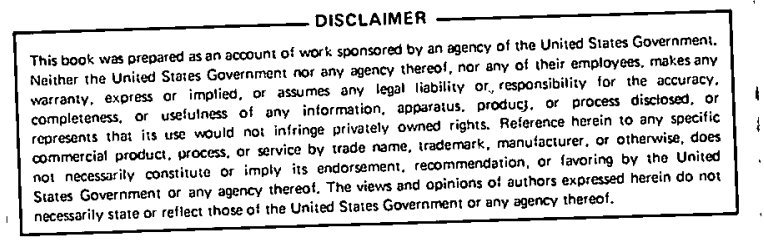

February 20, 1981

\section{Prepared for}

U.S. Department of Energy

Through an agreement with

National Aeronautics and Space Administration

by

Jet Propulsion Laboratory

California Institute of Technology

Pasadena, California 
Prepared by the Jet Propulsion Laboratory, California Institute of Technology, for the Department of Energy through an agreement with the National Acronautics and Space Administration.

The JPL Low-Cost Solar Array Project is sponsored by the Department of Energy (DOE) and forms part of the Solar Photovoltaic Conversion Program to initiate a major effort toward the development of low-cost solar arrays.

This report was prepared as an account of work sponsored by the United States Government. Neither the United States nor the United States Department of Energy, nor any of their employees, nor any of their contractors, subcontractors, or their employees, makes any warranty, express or implied, or assumes any legal liability or responsibility for the accuracy, completeness or usefulness of any information, apparatus, product or process disclosed, or represents that its use would not infringe privately owned rights. 


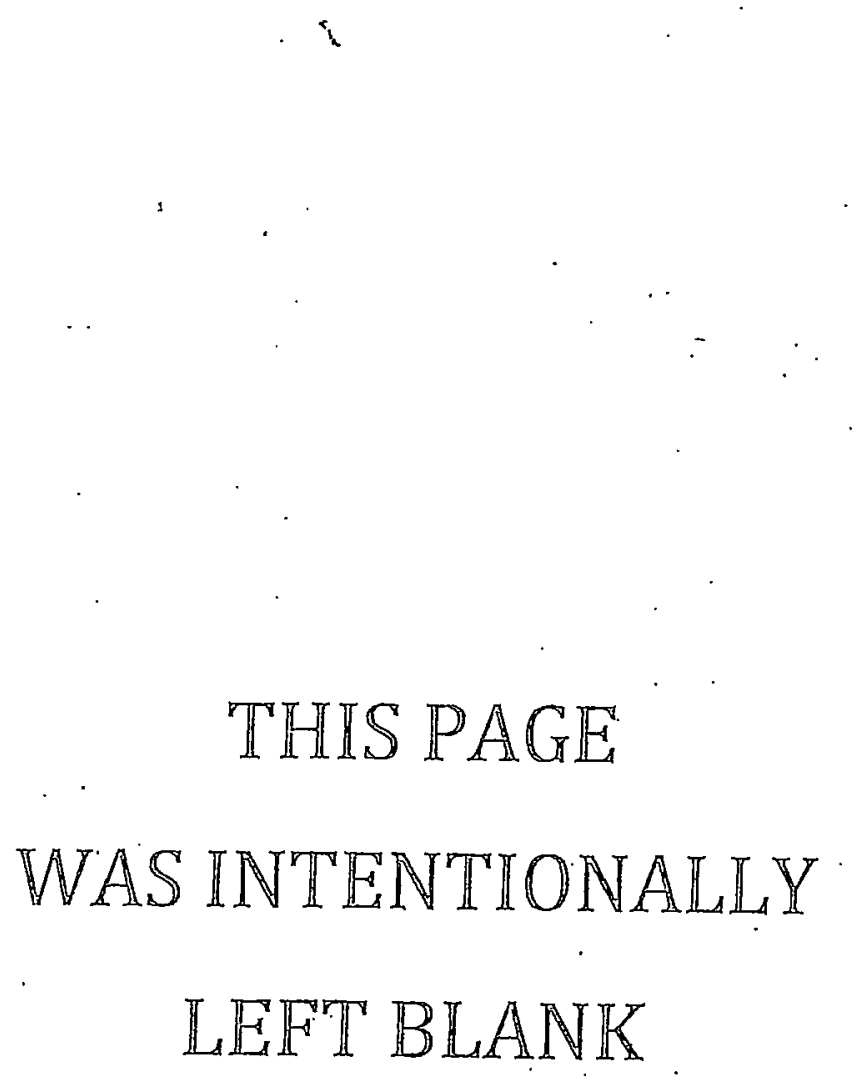


This specification was prepared by the Engineering Area of the Low-Cost Solar Array Project. Inquiries concerning details of the document, or requests for additional information, should be directed to R. G. Ross Jr., Engineering Area Manager, or J. C. Arnett, Cognizant Module Design Engineer. 


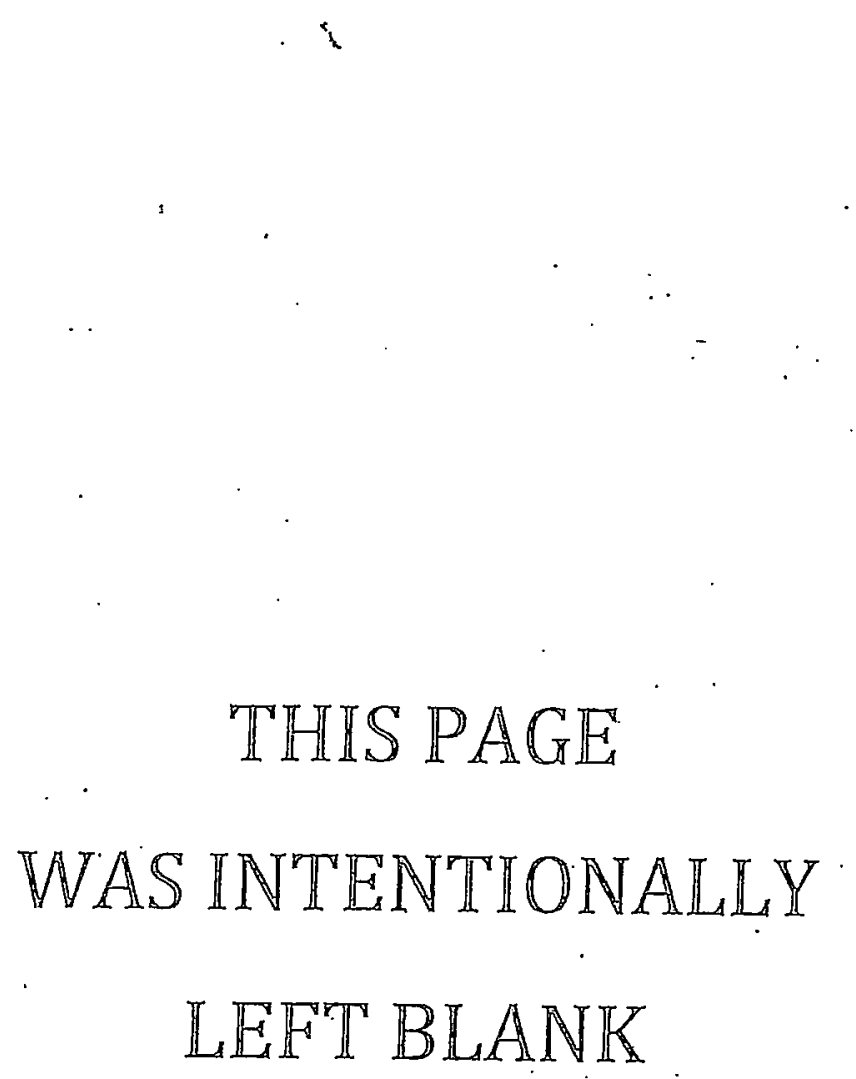


CONTENTS

I. INTRODUCTION . . . . . . . . . . . . . . . . . 1-1

A. SCOPE ......................... . . . . .

B. APPLICABLE DOCUMENTS .................. . . 1-1

II. DESIGN AND PERFORMANCE REQUIREMENTS . . . . . . . . . . . . . 2-1

A. PERFORMANCE REQUIREMENTS . . . . . . . . . . . . . 2-1

B. ELECTRTCAL DESIGN REQUIREMENTS . . . . . . . . . . 2-2

C. MECHANICAL DESIGN REQUIREMENTS . . . . . . . . . . . . 2-4

D. ENVIRONMENTAL DESIGN REQUIREMENTS . . . . . . . . . . 2-8

III. CHARACTERIZATION, QUALIFICATION AND ACCEPTANCE

TEST REQUIREMENTS . . . . . . . . . . . . . . . . . 3-1

A. PERFORMANCE CHARACTERIZATION TEST REQUIREMENTS . . . . . . 3-1

B. DESIGN QUALIFICATION TEST REQUIREMENTS . . . . . . . . . 3-1

C. MODULE PRODUCTION ACCEPTANCE REQUIREMENTS . . . . . . . 3-4

IV. PERFORMANCE MEASUREMENT PROCEDURES . . . . . . . . . . . . . . 4-1

A. ElECTRICAL PERFORMANCE ................. . . 4-1

V. ENVIRONMENTAL TEST PROCEDURES . . . . . . . . . . . . . . . 5-1

A. THERMAL CYCLE TEST PROCEDURE . . . . . . . . . . . . 5-1

B. HUMIDITY-FREEZING CYCLE TEST PROCEDURE . . . . . . . . . 5-1

C. MECHANICAL LOADING TEST PROCEDURE . . . . . . . . . . 5-1

D. TWISTED-MOUNTING SURFACE TEST PROCEDURE : . . . . . . . 5-1

E. HAIL-IMPACT TEST PROCEDURE . . . . . . . . . . . . 5-3

APPENDIXES

A. DETERMINATION OF NOMINAL OPERATING CELL TEMPERATURE... A-1

B. DETERMINATION OF TEMPERATURE CORRECTION COEFFICIENTS . - • B-1

C. HOT-SPOT ENDURANCE TEST PROCEDURE . . . . . . . . . . C-1 
2-1. Module-Panel Mounting Interface . . . . . . . . . 2-5

2-2. Module Standard Dimensions . . . . . . . . . . 2-6

3-1. Characterization and Qualification Test Flow Plan .... 3-3

5-1. Thermal Cycle Test . . . . . . . . . . . . 5-2

5-2. Humidity-Freezing Cycle Test . . . . . . . . . . 5-2

5-3. Graphic Representation of Twisted Mounting Surface Requirement ................ 5-3

A-1. Typical Cell Temperature Data . . . . . . . . . A-3

A-2. NOCT Correction Factor ............. . . A-4

C-1. Typical Reverse-Voltage I-V Plot for a Sample of Cells . . C-3

C-2. Effect of Test-Cell Illumination Level on

Hot-Spot Power Dissipation... . . . . . . . . . . C-4 


\section{SECTION I}

INTRODUCTION

A. SCOPE

This document establishes the requirements for the design and test of terrestrial solar cell modules for one phase of DOE's Low-Cost Solar Array Project. Intermediate-load modules designed to meet this specification will generally have the following design features and characteristics:

(1) Nominal Operating Voltage $\left(\mathrm{v}_{\mathrm{no}}\right)$ between $5 \mathrm{Vdc}$ and $20 \mathrm{Vdc}$

(2) Ability to be series-connected to worst-case open-circuit voltages of $1000 \mathrm{Vdc}$.

(3) Dimensions not exceeding $1.22 \mathrm{~m} \times 2.44 \mathrm{~m}(4 \mathrm{ft} \times 8 \mathrm{ft})$.

(4) Flat-plate configuration (non-concentrating).

(5) Output power referenced to Nominal Operating Conditions (NOC) and $v_{\text {no }}$.

In addition to module design and performance requirements, a series of characterization and qualification tests are also specified.

\section{B. APPLICABLE DOCUMENTS}

The following documentation is applicable to the extent specified herein. In the event of conflict between this specification and these documents, this specification shall apply.

(1) Energy Research and Development Administration. TM73702, ERDA/NASA/1022-77/16, "Terrestrial Photovoltaic Measurement Procedures," June 1977, Lewis Research Center, Cleveland, Ohio 44135 .

(2) Jet Propulsion Laboratory documents:

(a) Drawing No. 10082854, Latest Revision, Interface Control Drawing for LSA ILC Module.

(b) Moore, D., Cyclic Pressure-Load Developmental Testing of Solar Panels, JPL Document 5101-19, February 1977.

(c) Moore, D., and Wilson, A., Photovoltaic Solar Resistance to Simulated Hail, JPL Document 5101-62, October 15, 1978.

(d) Hoffman, A. R., and Miller, E. L., Bias-Humidity Testing of Solar Cell Modules, JPL Document 5101-84, October 15, 1978 . 
(e) Bishop, W., and Anhalt, K., Acceptance/Rejection Criteria for JPL/LSA Modules, Revision B, JPL Document 5101-21, November 3, 1978.

(f) Interim Standard for Safety -- Flat-Plate Photovoltaic Modules and Panels, Volume I, Construction Requirements, JPL Document 5101-164, November 30, 1980. 


\title{
SECTION II
}

\author{
DESIGN AND PERFORMANCE REQUIREMENTS
}

Solar cell modules meeting the requirements of this document will be mounted or grouped into array structures compatible with system design constraints for intermediate-load-center (ILC) applications ranging from $10 \mathrm{~kW}$ to $500 \mathrm{~kW}$. Such applications are typified by apartment complexes, waterpumping installations, shopping centers, and small industrial facilities.

The module design shall satisfy general design requirements including consideration of features that will minimize possible degradation of module performance and physical properties resulting from solar exposure, environmental weathering, soiling, mechanical loading, and array shadowing. In addition to these general considerations, the specific performance and design requirements set forth below shall be met by the modules:

The use of concentrators shall not be considered in meeting these requirements.

\section{A. PERFORMANCE REQUIREMENTS}

The following standard performance measurement and reporting requirements shall be used:

\section{Nominal Operating Voltage}

The Nominal Operating Voltage $\left(\mathrm{V}_{\mathrm{no}}\right)$ is the reference voltage at which modules are designed to provide maximum output power at NOC. NOC is defined as an irradiance level of $80 \mathrm{~mW} / \mathrm{cm}^{2}$, Air Mass 1.5 spectrum, and cell temperature equal to the Nominal operating Cell Temperature (NOCT). For purposes of integration in ILC applications, $V_{\text {no }}$ shall be not less than 5 Vdc. For purposes of standardization, it is recommended that $V_{\text {no }}$ be 15.0 Vdc; however, a convenient fraction of $15 \mathrm{Vdc}$, such as 5, 7.5, 10, or $20 \mathrm{Vdc}$, may be selected. For safety reasons, $V_{\text {no }}$ shall in all cases be selected such that the maximum open-circuit voltage $\left(V_{o c}\right)$ shall not exceed $30 \mathrm{Vdc}$ under worst-case conditions of $100 \mathrm{~mW} / \mathrm{cm}^{2}$ and $0^{\circ} \mathrm{C}$, cell temperature.

\section{Module Output Power}

Module Output Power ( $P$ ) for individual modules shall be determined by measurements referenced to NOC and $V_{\text {no }}$, in accordance with the procedures described in Section IV, Part A. For purposes of accepting production modules, the Average Module Output Power ( $P_{\text {avg }}$ ) shall be established by measurement of $P$ for a suitably-sized sample quantity of modules (not fewer than 10). 


\section{Minimum Individual Module Output Power}

The minimum acceptable output power $\left(P_{\min }\right)$ for individual production modules shall be not less than $90 \%$ of the pre-determined $P_{\text {avg }}$.

\section{Module Peak Power Rating}

The peak power rating $\left(P_{p}\right)$ of the module shall be stated at 100 $\mathrm{mW} / \mathrm{cm}^{2}$ irradiance, $\mathrm{AM} 1.5$ spectrum, and $25^{\circ} \mathrm{C}$ cell temperature on the basis of measurement of the average maximum power of the same sample used to establish $P_{\text {avg. }}$.

\section{Nominal Operating Cell Temperature}

NOCT is the average cell junction temperature in the field under typical operating conditions and is specifically defined so that the array efficiency $(\eta)$ at $80 \mathrm{~mW} / \mathrm{m}^{2}$, NOCT, multiplied by the average annual incident irradiance on the array $(H)$ equals the annual electrical energy produced by the array; i.e.,

$$
\mathrm{E}=\eta \times \mathbf{H}
$$

where

$$
\begin{aligned}
E= & \text { total annual electrical energy }\left(\mathrm{kW}-\mathrm{hr} / \mathrm{m}^{2}\right) \\
\eta= & \text { array efficiency at NOCT, } 80 \mathrm{~mW} / \mathrm{m}^{2} \\
H= & \text { average annual irradiance on array at site of interest } \\
& \left(\mathrm{kWh} / \mathrm{m}^{2} / \text { year }\right) .
\end{aligned}
$$

Studies* have shown that a working definition for Nocr that meets the above conditions is the module cell temperature corresponding to operation under the following specific Nominal Thermal Environment (NTE):

$$
\begin{aligned}
& \text { Irradiance }=80 \mathrm{~mW} / \mathrm{cm}^{2} \\
& \text { Air temperature }=20^{\circ} \mathrm{C} \\
& \text { Wind average velocity }=1 \mathrm{~m} / \mathrm{sec}
\end{aligned}
$$

\footnotetext{
*Stu1tz, J. W., Thermal and Other Tests of Photovoltaic Modules Performed in Natural Sunlight, JPL Publication 5101-76, July 31, 1978, and Ross, R. G., and Gonzalez, C. C., Reference Conditions for Reporting Terrestria 1 Photovoltaic Performance, Proceedings of AS/ISES 1980 Annual Meeting, Phoenix, Arizona, June 2-6, 1980.
} 
The NOCT measurement shall be made by the procedure described in Appendix A.

\section{B. ELECTRICAL DESIGN REQUIREMENTS}

The electrical design of the module shall meet the following requirements:

\section{Electrical Voltage Isolation}

All module circuitry, including output terminations, shall be insulated from external surfaces. The voltage isolation design shall provide capability of withstanding a worst-case, open-circuit system voltage of 1000 $V d c$, when modules are connected in series, at $100 \mathrm{~mW} / \mathrm{cm}^{2}$ irradiance and $0^{\circ} \mathrm{C}$ cell temperature. This capability shall be demonstrated by ability to withstand the $3000 \mathrm{Vdc}$ high-voltage (hi-pot) test of Section III, Part B, Paragraph 4.

\section{Electrical Grounding and Safety Construction Requirements}

In order to minimize hazards, all modules shall meet the requirements contained in Interim Standard for Safety - Flat- Plate Photovoltaic Modules, Volume I, Construction Requirements, JPL Document 5101-164, November 30, 1980. Because of the provisional nature of this document, requests for exceptions to specific requirements will be considered on a case-by-case basis at JPL's discretion.

\section{Module Electrical Interface}

The output terminations shall provide reliable connection to the module internal circuitry (cell strings) and shall have current-handling capability compatible with module short-circuit current. Corrosion-resistant materials and finishes shall be selected for terminations. Threaded stud terminations, if employed, shall be provided with a suitable enclosure or cover to prevent accidental exposure of any person to shock hazard. Threaded studs shall be of sufficient mechanical strength to withstand required fastener torque without loss of continuity to internal circuitry. Pigtails, if provided, shall be of sufficient length to provide connection to adjacent modules. The polarity of each termination shall be identified in accordance with the requirements of Section II, Part $C$, Paragraph 4, below.

\section{Cell String Reliability and Redundancy}

Circuit redundancy features shall be incorporated so that the loss in module output power at NOC shall be less than $10 \%$ under any of the following failure conditions:

(1) A single solar cell is separated into two parts by a single straight-line crack with any orientation or position within the cell. 
(2). A single interconnect attachment point to a single solar cell is open-circuited.

(3) A single solar cell is short-circuited.

\section{Module Hot-Spot Endurance}

The module sha11, be capable of withstanding, for its design life, the hot-spot heating caused when the module is short-circuited at $100 \mathrm{~mW} / \mathrm{cm}^{2}$ solar irradiance, $40^{\circ} \mathrm{C}$ air temperature, and any of the following conditions occur:

(1) Shadowing of any portion of any single solar cell.

(2) Separation of any single solar cell into two parts by a single straight-line crack with any orientation or position within the cell.

(3) Open-circuiting of any single interconnect attachment point to any single solar cell.

(4) Short-circuiting of any single solar cell.

This capability shall be demonstrated by ability to withstand the Hot-Spot Endurance Test of Section III, Part B, Paragraph 5.

\section{MECHANICAL DESIGN REQUIREMENTS}

The mechanical design of the module shall meet the following requirements :

\section{Module Geometrry}

The maximum module dimensions shall not exceed $1.22 \times 2.44 \mathrm{~m}$ $(4 \times 8 \mathrm{ft}$ ). Mounting may be by means of through-fasteners or clamps. It is preferred that module dimensions and mounting provisions be designed to interface with the panel structure shown in Figure 2-1. However, when modules are provided with individual support frames, it is recommended that the dimensions and mounting pattern shown in Figure 2-2 be used. An Interface Control Drawing* shall be prepared by the manufacturer or contractor, providing at a minimum the following information:

(1) Maximum envelope dimensions and tolerances.

(2) Location, configuration, and materials and finishes of output terminations, with applicable user constraints (e.g., fastener torque and polarity identification).

\footnotetext{
*JPL Drawing No. 10082854 provides a suggested format for a suitable Interface Control Drawing.
} 


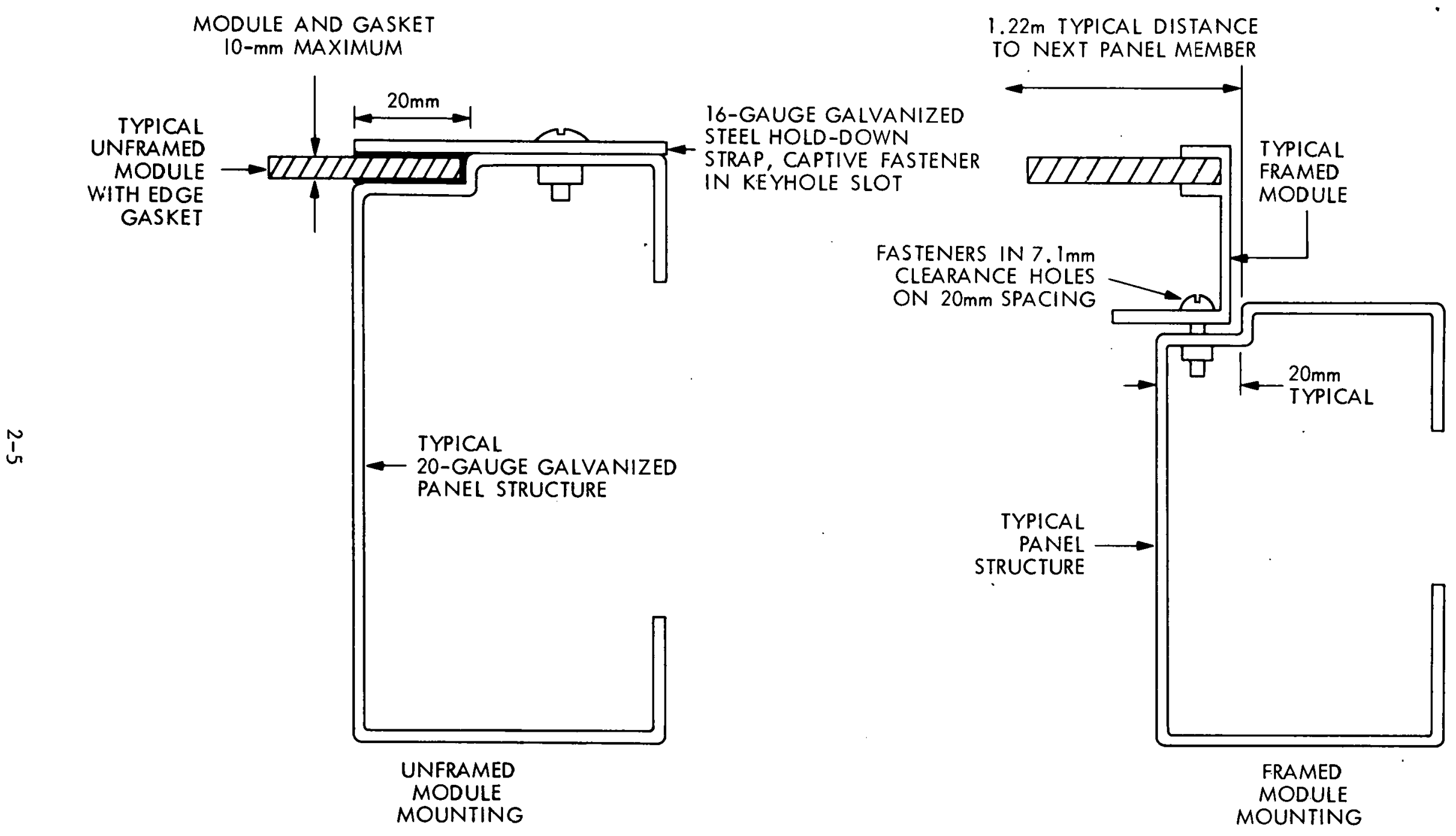

Figure 2-1. Module-Panel Mounting Interface 

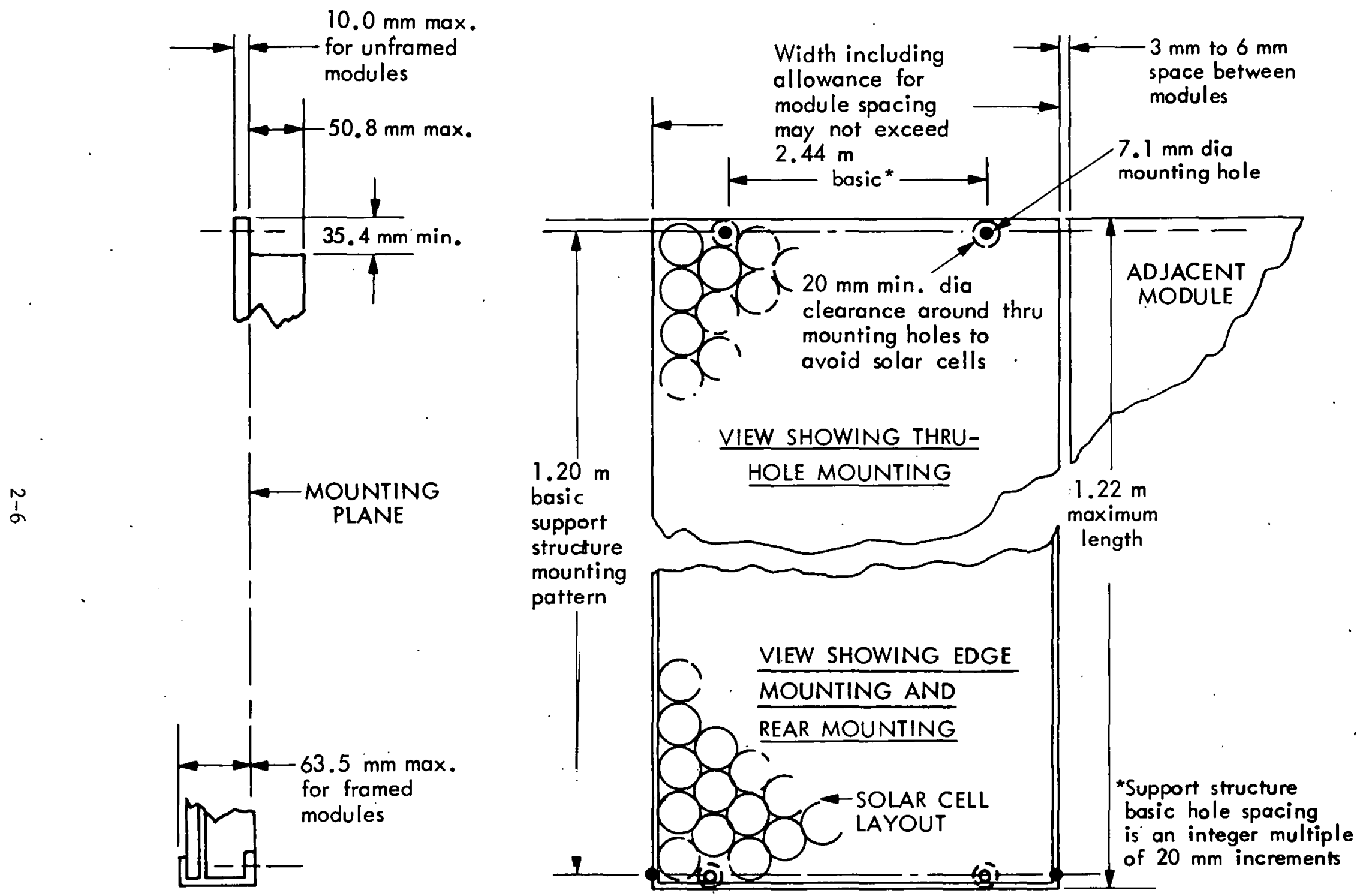

Figure 2-2. Module Standard Dimensions 
(3) Mounting hole or attachment provisions, materials and finishes of mounting surfaces or frames, dimensions, and tolerances.

(4) Illuminated (active) surface envelope dimensions and shadowing or view-angle constraints. The ratio of cell area to module maximum area shall be provided.

(5) Equipment grounding configuration, including location, materials and finishes, and user constraints (e.g., torque limits, surface sealing).

(6) A dimensioned cross-sectional view of the encapsulant systems through cells and interconnects.

(7) Dimensioned view(s) of both front and back contact cell-to-cel1 interconnect attachment geometry including strain-relief provisions.

(8) Electrical performance ( $P_{a v g}$ at $\mathrm{NOC}, \mathrm{V}_{\mathrm{no}} ; \mathrm{P}_{\mathrm{P}}$ at $100 \mathrm{~mW} / \mathrm{cm}^{2}, 25^{\circ} \mathrm{C}$ )

(9) NOCT

(10) Maximum weight.

(11) Detail and location of manufacturer's identification label and, if applicable, caution labels.

(12) Installation and interconnection details, including typical system mechanical, electrical, and configuration constraints for a representative ILC array application.

\section{Interchangeability}

All modules from a given manufacturer shall be physically and functionally interchangeable. Any specialized equipment or tools required for module removal or replacement shall be fully described on the ICD. Tolerances on all external module dimensions shall be maintained to ensure module interchangeability. Surfaces, mounting holes, and any attachment hardware associated with the attachment interfaces shall be maintained within tolerances specified in the interface control drawing.

\section{Optical Surface Soiling}

The exposed optical surface(s) of the module shall be smooth and generally free of projections that could promote entrapment of dust and other debris. Particular attention shall be given to selection of materials for the optical surface(s) that will minimize the accumulation of non-removable contaminants, particulate matter and stains, and will promote self-cleaning by natural processes such as wind and rain. 


\section{Module Labeling and Identification}

Each module shall be identified in a permanent and legible manner with suitable labels or markings specifying the manufacturer's module model number (or drawing) and revision, sequential serial number, and maximum system operating voltage for which the module is designed. Additional information may include $V_{\text {no }}$ and $P_{\text {avg. The }}$. Thentification shall be installed at a position that is accessible when the module is installed in the array. The polarity of each electrical termination shall be marked in a permanent and legible manner. Polarity marking shall be visible when acquiring access to the electrical terminations in a completed array.

\section{ENVIRONMENTAL DESIGN REQUIREMENTS}

Environments to be considered in assessing possible degradation of module electrical performance and physical properties include: solar exposure, particularly UV; thermal conditions, including freezing and thawing; effects of humidity, rain, snow, ice, hail, salt mist, and atmospheric oxidants; dust and debris accumulation; non-removable stains or contamination, and dynamic loading effects of wind, snow, hail, and mechanical handling. As a minimum, the module design shall be capable of withstanding exposure to the following environmental test environments:

(1) Thermal cycle test from $-40^{\circ} \mathrm{C}$ to $+90^{\circ} \mathrm{C}$ in accordance with the Test Procedure in Section V, Part A, of this specification.

(2) Humidity-freezing cycle test in accordance with the Test Procedure in Section V, Part B.

(3) Mechanical cyclic loading in accordance with the Test Procedure in Section V, Part C. The test load level shall be $2.4 \mathrm{kPa}$ (50 $\left.\mathrm{lb} / \mathrm{ft}^{2}\right)$.

(4) Iwisted mounting surface of $20 \mathrm{~mm} / \mathrm{m}(.25 \mathrm{in} . / \mathrm{ft})$ in accordance with the Test Procedure in Section V, Part $D$.

(5) Hail impact testing in accordance with the Test Procedure in Section V, Part E. The module shall be capable of withstanding $25.4 \mathrm{~mm}$ ( 1.0 in.)-dia simulated hailstone impact. 
SECTION III

CHARACTERIZATION, QUALIFICATION AND ACCEPTANCE TEST REQUIREMENTS

\section{A. PERFORMANCE CHARACTERIZATION TEST REQUIREMENTS}

The tests included in this section shall be performed to characterize module electrical and thermal performance. The characterization testing shall be performed in the sequence shown in the flow diagram in Figure 3-1.

\section{Determination of Nominal Operating Cel1 Temperature}

For purposes of providing a measurement of module performance that is representative of the expected terrestrial application, module performance measurements are referenced to the NOCT. NOCT is determined by measuring the average cell temperature in the module under ambient conditions equivalent to the NTE. The NTE is characterized by $80 \mathrm{~mW} / \mathrm{cm}^{2}$ insolation, ambient air temperature of $20^{\circ} \mathrm{C}$ and average wind velocity of $1.0 \mathrm{~m} / \mathrm{sec}$, with the module mounted to simulate the application thermal boundary conditions, and electrical output terminations open-circuited. Actual cell temperatures shall be taken at conditions approximating NTE in order to obtain the solar cell NOCT. The approved techniques for performing the NOCT characterization test are included in Appendix A.

\section{Electrical Measurements}

Module power values are required at two sets of operating conditions as follows: ( 1 ) at NOC and $V_{\text {no }}$ for Module Output Power ( $P$ ) and (2) at $100 \mathrm{~mW} / \mathrm{cm}^{2}$, AM $1.5,25^{\circ} \mathrm{C}$ and maximum power for Module Peak Power Rating $\left(P_{p}\right)$. Since it is unlikely that the operating conditions specified in the definition of the power values will exist during testing, these power values may be computed using procedures such as that described in Section IV, Part A, Paragraph 2. Therefore, in addition to determining NOCT as described above, it is necessary to determine temperature correction coefficients by a procedure such as that described in Appendix B. Note that that procedure is valid for a specific value of irradiance.

\section{B. DESIGN QUALIFICATION TEST REQUIREMENTS}

This section specifies the minimum tests that shall be performed by the contractor or manufacturer in order to ensure that the modules will satisfy the design requirements of this specification and to provide confidence that production modules will function within the specified performance requirements.

Modules shall be mounted on structural test frames simulating the selected mounting interface and configuration for all design qualification testing.

Modules shall be provided with suitable circuit monitoring instrumentation. To the extent possible, the normal module output termination connections shall be used for this instrumentation. Temperature instrumentation (e.g. thermocouples) shall be installed on the module's rear 
surface, positioned directly behind a centrally located solar cell. At a minimum, the following qualification tests shall be performed in the order described below. For clarification, the test sequence is shown in the flow diagram (Figure 3-1).

\section{Baseline Electrical Measurement}

After assembly in the structural test frame, each module shall be measured to establish a baseline electrical output power that will serve as the comparison value for determination of the effects of qualification testing on electrical performance. The measurement shall be made in accordance with Section IV, Part A.

\section{Baseline Visual Inspection}

Each module shall be visually inspected to obtain a baseline determination of the presence or absence of defects in the module for purposes of detecting any changes after environmental exposure. Pertinent sections of the applicable acceptance or rejection criteria or workmanship specification shall provide a guide for this inspection.

\section{Ground Continuity Test}

Each module having exposed external conductive surfaces (i.e., frame, structural members or edge closures) shall be tested using a suitable continuity tester to verify that electrical continuity exists between all such surfaces and the module grounding point. Modules that use direct attachment to the array structure to obtain grounding shall be tested after assembly.

\section{Fiectrical Isolation Test}

Each module shall be subjected to both positive- and negativepolarity dc hi-pot testing conducted with the output terminations shortcircuited. Test leads from a suitable dc-voltage power supply shall be connected to the shorted terminals and the module grounding point. In the case of modules not required to provide an equipment ground stud, the mounting structure shall be used as the alternative test point. Voltage shall be applied at a rate not to exceed $500 \mathrm{~V} / \mathrm{sec}$ up to the test voltage of $3000 \mathrm{Vdc}$, and then held at the required test voltage for $1 \mathrm{~min}$. The module shall be observed during the test and there shall be no signs of arcing or flash-over. Dc leakage current shall be monitored during the test and shall not exceed $50 \mu \mathrm{A}$. Ac leakage current due to capacitive charging and power supply ripple shall not be considered. Dc leakage current during the test shall be recorded for each polarity.

\section{Hot-Spot Endurance Test}

One module shall be subjected to a hot-spot endurance test for a cumulative exposure period of $100 \mathrm{~h}$. The test shall be conducted using 


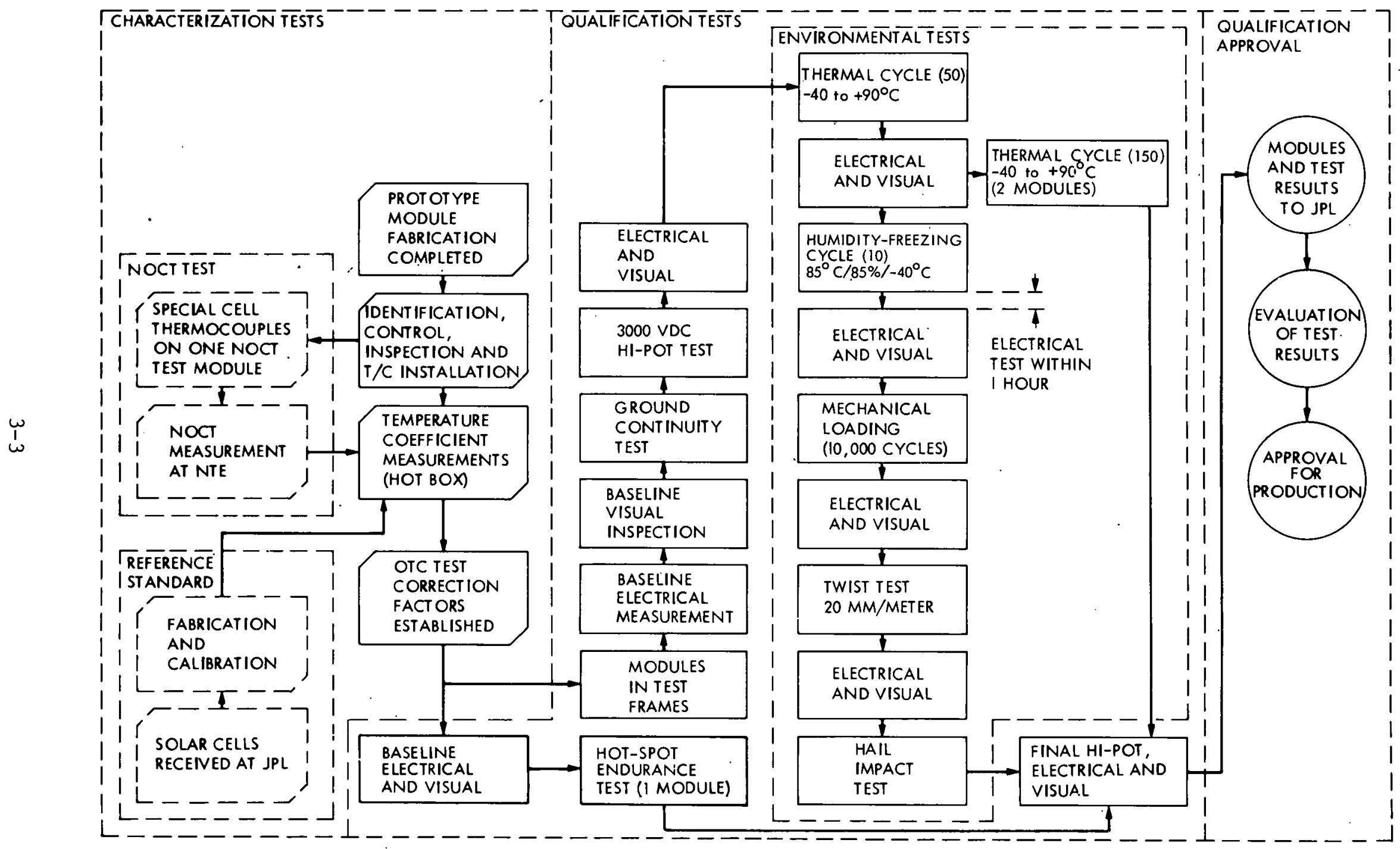

Figure 3-1. Characterization and Qualification Test Flow Plan 
the procedures described in Appendix C. The sample shall satisfy the criteria for qualification stated in Section III, Part B, Paragraph 7, at conclusion of the test. The sample subjected to the hot-spot endurance test shall not be subjected to the environmental test sequence (Section III, Part B, Paragraph 6).

\title{
6. Environmental Tests
}

Modules selected for environmental tests shall be subjected to the following exposures which are described in detail in Section $V$. Module electrical performance measurements and visual inspection shall be conducted after each exposure. The tests shall be conducted in the order indicated:

\author{
(1) Thermal cycle test. \\ (2) Humidity-freezing cycle test. \\ (3) Mechanica1 loading test. \\ (4) Twisted-mounting surface test. \\ (5) Hail impact test.
}

\section{Qualification Pass-or-Fail Criteria.}

The output power degradation of each tested module, determined after completion of all required qualification tests, shall not exceed $5 \%$ of the baseline electrical performance determined in accordance with Section III, Part B, Paragraph 1. The module shall not have exhibited any open-circuits or ground faults during performance of the environmental tests. The module shall pass the electrical isolation test (Section III, Part B, Paragraph 4) when retested at completion of qualification tests. The allowable level of observable cracks or other mechanical degradation (such as delamination of coatings) shall be that established by the JPL-approved visual inspection criteria for production modules (Section III, Part C, Paragraph 3).

\section{MODULE PRODUCTION ACCEPTANCE REQUIREMENTS}

Module acceptance shall be based on meeting the following requirements:

1. Electrical Performance

Each module shall be measured to obtain its current-voltage characteristics ( $I-V$ curve). The module output power at NOC and $V_{\text {no }}$ shall be determined in accordance with Section IV, Part A. No module shall be accepted for delivery that produces less than $90 \%$ of the $\mathrm{P}_{\text {avg }}$, established under Nominal Operating Conditions. 


\section{Electrical Isolation}

Each module shall withstand the dc hi-pot test, in accordance with Section III, Part B, Paragraph 4, to assure adequate electrical isolation for personal safety.at system operating voltages.

\section{Mechanical and Visual Inspection}

Modules shall be mechanically and visually inspected on the basis of criteria developed by the manufacturer and approved by JPL, defining acceptable and rejectable standards of workmanship and quality. Acceptance/ Rejection Criteria for JPL/LSA Modules, JPL Document 5101-21, Revision B, November 3, 1978, provides guidelines for development of suitable criteria. 


\section{A. ELECTRICAL PERFORMANCE}

Electrical performance measurements shall be referenced to Noc, defined as $80 \mathrm{~mW} / \mathrm{cm}^{2}$ irradiance, AM1.5, NOCT. All procedures, equipment and standards related to measurements shall conform to the current revision of Terrestrial Photovoltaic Measurement Procedures, NASA TM 73702. A reference cell which has spectral response representative of the cells in the module shall be the only irradiance reference used. Secondary standards or transfer modules shall not. be used.

To provide for efficient module testing, module performance measurements may be conducted at either NOC conditions or at Optional Test Conditions (OTC), defined as $80 \mathrm{~mW} / \mathrm{cm}^{2}$ irradiance and a cell temperature other than NOCT, and then corrected to the required reporting conditions.

1. Module Output Power Measurements at NOC

When module performance is measured at NOC, the individual module output power shall be calculated as the product of $V_{\text {no }}$ and the module current taken from the $I-V$ characteristic curve at $V_{n o}$ :

$$
P=V_{\text {no }} \cdot I_{\text {NOCT }}
$$

where

$$
\begin{aligned}
\mathrm{P} & =\text { individual module output power } \\
\mathrm{V}_{\text {no }} & =\text { module nominal operating voltage at NOCT } \\
\mathrm{I}_{\text {NOCT }} & =\text { module current at NOCT and } \mathrm{V}_{\text {no }}
\end{aligned}
$$

2. Module Output Power Measurements at OTC

When module performance is measured at OTC, the individual module output power must be determined by application of appropriate temperature correction coefficients to the voltage and current data obtained from the OTC $I-V$ characteristic curve. Under these conditions the module output power is calculated directly from:

$$
\mathrm{P}=\mathrm{V}_{\mathrm{no}}\left(\mathrm{I}_{\mathrm{OTC}}+\Delta \mathrm{I}\right)
$$

where

$$
\begin{array}{ll}
I_{O T C} & =\text { current at } V_{\text {OTC }} \text { from OTC I-V curve } \\
\Delta \mathrm{I} & =\text { current temperature correction, amperes }
\end{array}
$$




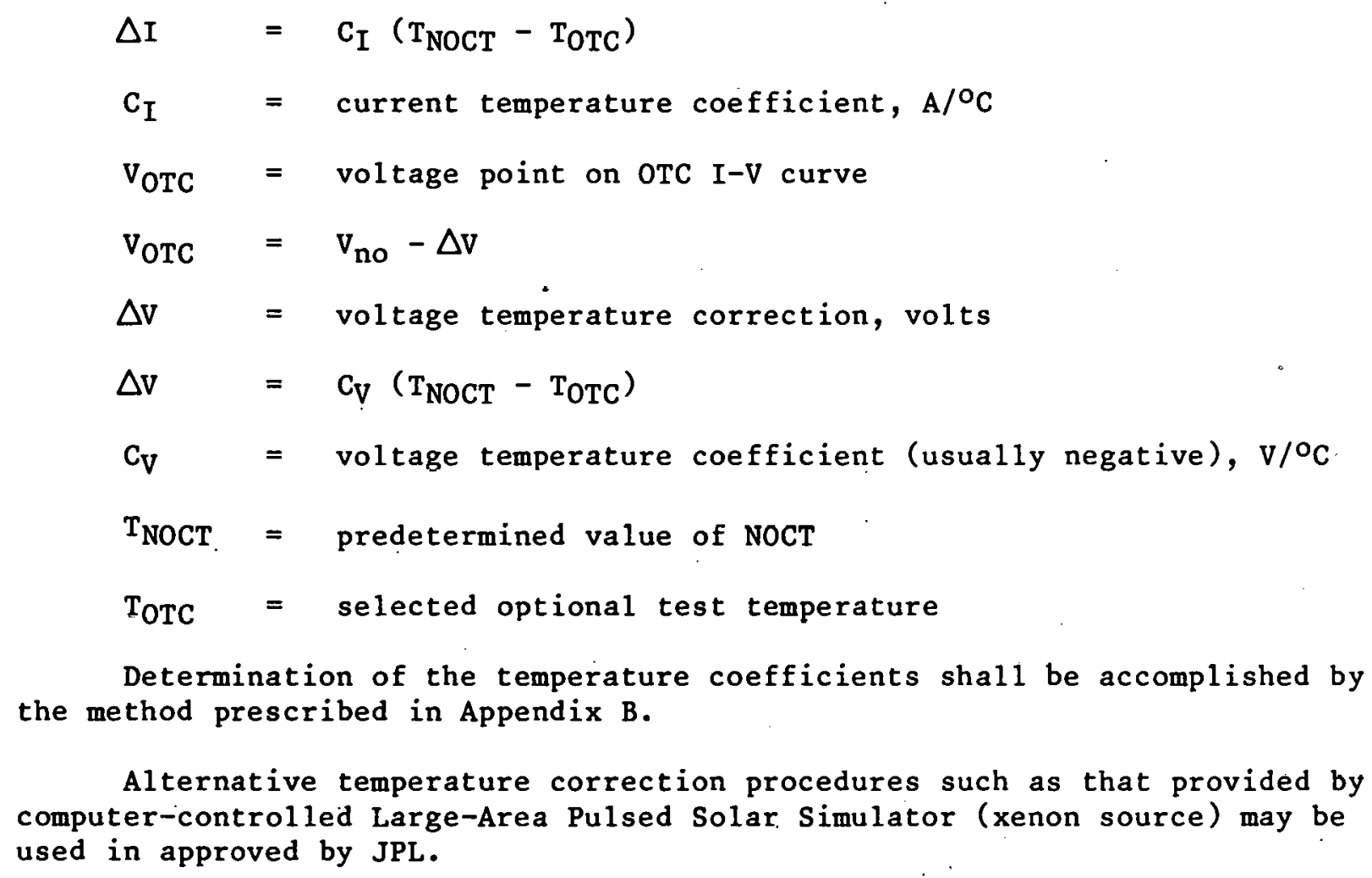
the method prescribed in Appendix B.

Alternative temperature correction procedures such as that provided by computer-controlled Large-Area Pulsed Solar. Simulator (xenon source) may be used in approved by JPL. 


\title{
SECTION V
}

\author{
ENVIRONMENTAL TEST PROCEDURES
}

\section{A. THERMAL CYCLE TEST PROCEDURE}

Sample modules shall be subjected to the thermal cycle test in accordance with the profile shown in Figure 5-1, with the cell temperature varying between $-40^{\circ} \mathrm{C}$ and $+90^{\circ} \mathrm{C}$. The temperature shall vary approximately linearly with time at a rate not exceeding $100^{\circ} \mathrm{C} / \mathrm{h}$ and with a period not greater than $6 \mathrm{~h}$ per cycle (from ambient to $-40^{\circ} \mathrm{C}$ to $+90^{\circ} \mathrm{C}$ to ambient). The module circuitry shall be instrumented and monitored throughout the test to verify that no open circuits or ground faults occur during the exposure. All environmental test modules shall receive 50 cycles of exposure. Two samples shall be returned to test after the initial 50 cycles for a total accumulation of 200 cycles while 50-cycle-only samples (two modules, minimum) are subjected to other environmental tests.

\section{B. HUMIDITY-FREEZING CYCLE TEST PROCEDURE}

The module shall be subjected to a humidity-freezing cycle test in accordance with the profile shown in Figure 5-2. The module circuitry shall be instrumented to verify that no open circuits or ground faults occur during the exposure. The electrical performance test, in accordance with Section IV, Part A, shall be performed within $1 \mathrm{~h}$ after removal from the humidity chamber, or within another mutually agreed-upon time period if the testing is subcontracted.

\section{MECHANICAL LOADING TEST PROCEDURE}

Pane1-type modules shall be subjected to a cyclic load test in which the module is supported only at the design support points and a uniform load normal to the module surface is cycled 10,000 times in alternating negative and positive directions. Cycle rate shall not exceed 20 cycles/min. The module circuitry shall be instrumented to verify that no open circuits or ground faults occur during the test. Cyclic Pressure-Load Developmental Testing of Solar Pane1s, JPL Document 5101-19, February 1977, describes techniques suitable for the performance of this test.

\section{TWISTED-MOUNTING SURFACE TEST PROCEDURE}

The module shall be subjected to a twist test by deflection of the structure or surface to which it is mounted. The deviation from a true flat surface during the test shall be $20 \mathrm{~mm} / \mathrm{m}(0.25 \mathrm{in}$. per foot), measured along either mounting surface in the direction of the module's width, as shown in Figure 5-3. The module circuits shall be instrumented to verify that no open. circuits or ground faults occur during the deflection test. 


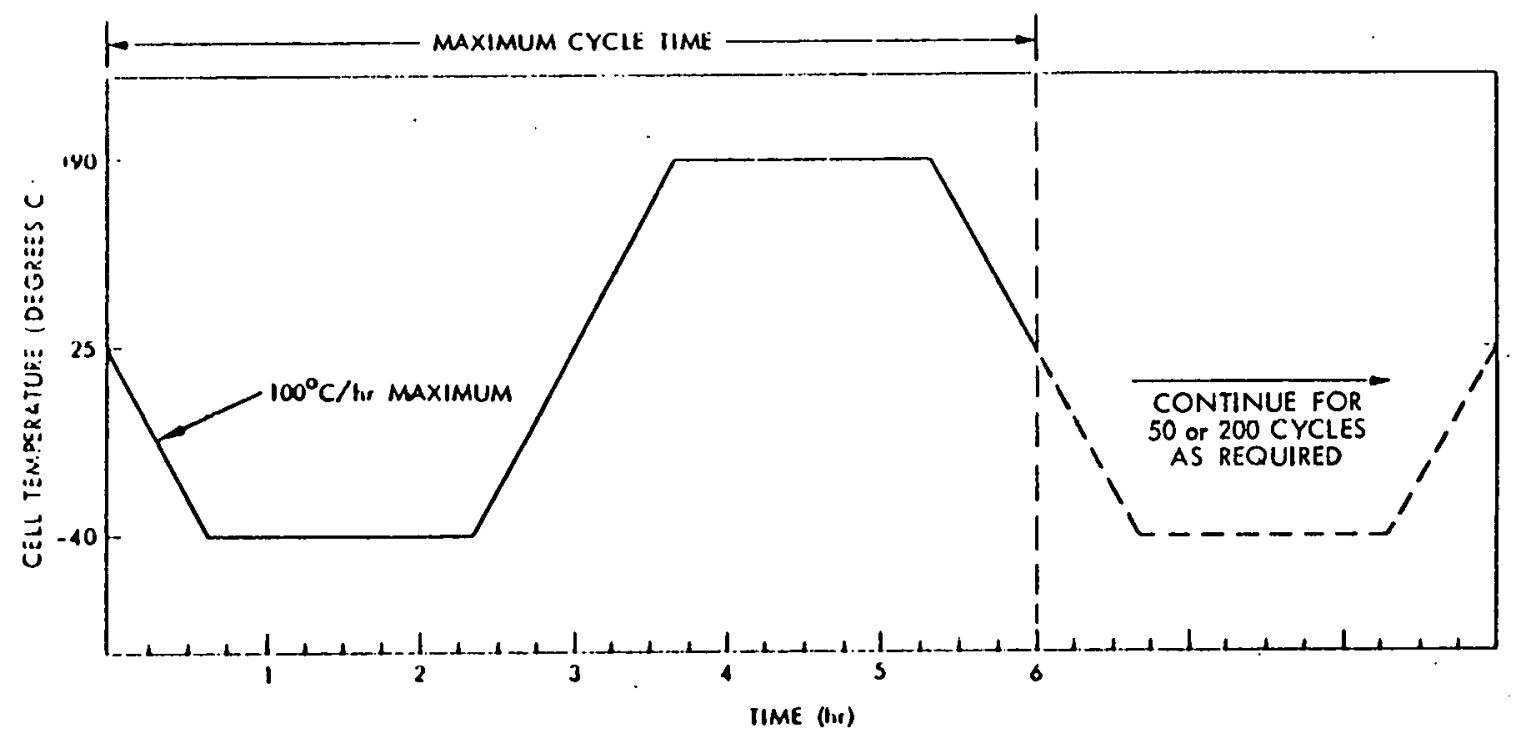

Figure 5-1. Thermal Cycle Test (Shorter cycle time is acceptable if $1000^{\circ} \mathrm{C} / \mathrm{hr}$ maximum rate of temperature change is not exceeded. Chamber may be opened at 25 -cycle intervals for visual inspection.)

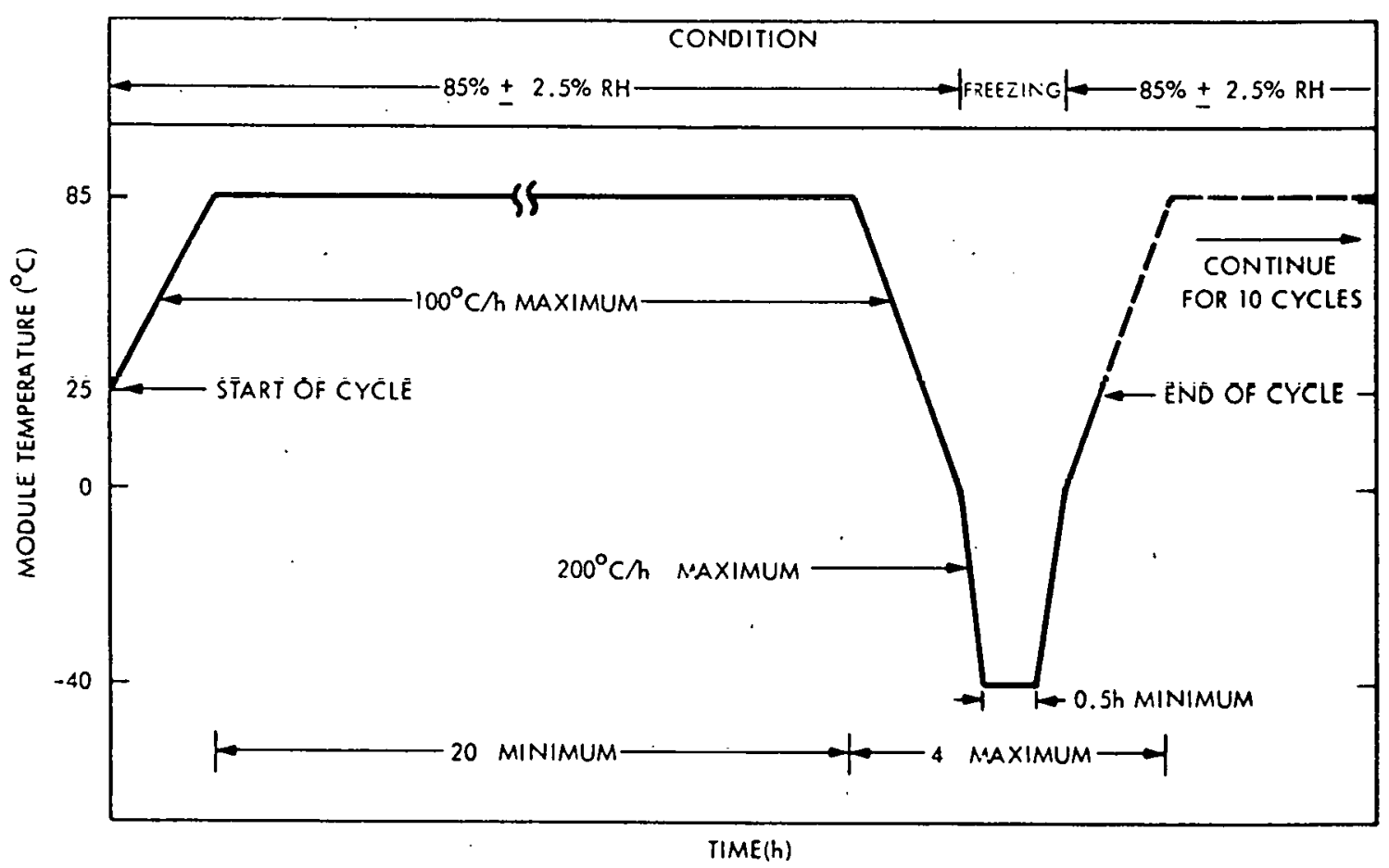

Figure 5-2. Humidity-Freezing Cycle Test 


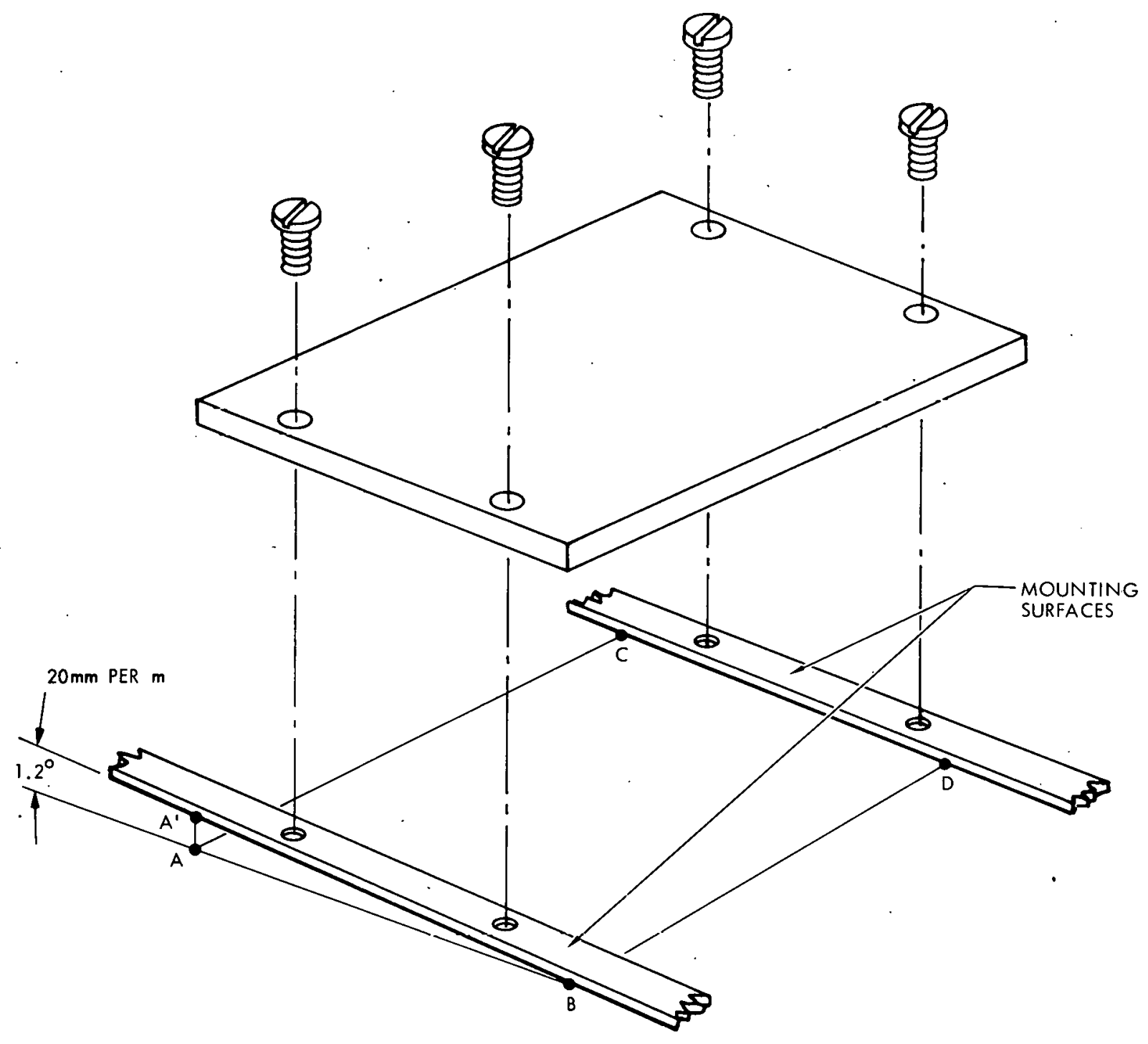

Figure 5-3. Graphic Representation of Twisted-Mounting Surface Requirement. Points A, B, C, D are in a Plane; Point $A^{\prime}$ is out of Plane by the Amount Shown

\section{E. HAIL-IMPACT TEST PROCEDURE}

The module shall be subjected to normal impact loading with 25.4-mm ( 1 in.)-dia ice balls traveling at terminal velocity of $23.2 \mathrm{~m} / \mathrm{sec}$ ( $52 \mathrm{mph}$.

At least 10 of the specimen's most sensitive points shall be selected for impact. The most sensitive exposed points on a test specimen may be determined experimentally through destructive testing of a sample panel. Ice balls of $25 \mathrm{~mm}(1.0 \mathrm{in.})$ dia shall be fired at candidate sensitive points with increasing velocity until the panel is broken. Several different points on the panel should be broken, and the points broken at the lowest velocities should be used for subsequent testing. 
The candidate points selected should include (where applicable) the following:

(1) Center points of cells.

(2) Corners and edges of the module.

(3) Edges of cells, especially around electrical contacts.

(4) Points of minimum spacing between cells.

(5) Points of support for any superstrate material.

(6) Points of maximum distance from points of support in (5).

Error of up to $13 \mathrm{~mm}(0.5 \mathrm{in.})$ in the location of a hit is acceptable. Either pneumatic or spring-actuated guns for projecting the ice-balls against the modules are acceptable. However, ice-ball velocity at impact must be controlled to within $+5 \%$ of specified velocity for the required hailstone size. Ice balls shal $\overline{1}$ be generally spherical in shape with a maximum deviation in diameter of $3 \mathrm{~mm}(0.125 \mathrm{in.})$. The iceballs shall be cooled to $-10^{\circ} \mathrm{C}+2{ }^{\circ} \mathrm{C}$ as measured in the compartment where they are stored. The module shall be mounted in manner representative of that used for actual installation of the module in the array. After each impact, the module shall be inspected for visible evidence of damage. Note that ice balls are the only acceptable hailstone simulation. Steel balls, for example, shall not be used. Resistance of Photovoltaic Solar Panels to Simulated Hail, JPL Document 5101-62, April 1978, describes techniques and equipment suitable for performance of this test. 


\section{APPENDIX A}

DETERMINATION OF NOMINAL OPERATING CELL TEMPERATURE

1. Purpose

The purpose of this test is to acquire sufficient data to allow an accurate determination of the nominal operating temperatures of the solar cells of a terrestrial solar array module.

A working definition for NOCT is the module cell temperature corresponding to operation under the following specific Nominal Thermal Environment (NTE):

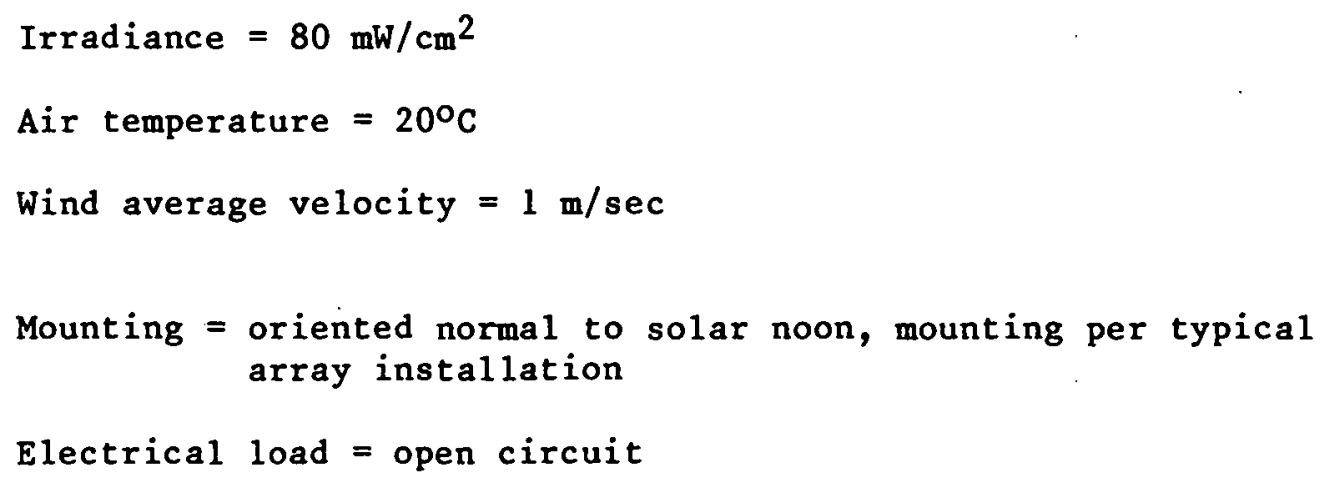

The NOCT test procedure is based on gathering actual measured cell temperature data by means of thermocouples attached directly to the cells of interest, for a range of environmental conditions similar to the NTE. The data are then presented in a way that allows accurate and repeatable interpolation of the NOCT temperature.

\section{Determination of NOCT}

The temperature of the solar cell $\left(\mathrm{T}_{\mathrm{cell}}\right)$ is primarily a function of the air temperature $\left(T_{a i r}\right)$, the average wind velocity $(\bar{v})$, and the total solar irradiance (L) impinging on the active side of the solar array module. The approach for determining NOCT is based on the fact that the temperature difference $\left(\mathrm{T}_{\mathrm{ce}} 11^{-\mathrm{T}_{\mathrm{air}}}\right)$ is largely independent of air temperature and is essentially linearly proportional to the irradiance level. Analyses indicate that the linear assumption is quite good for irradiance levels greater than about $40 \mathrm{~mW} / \mathrm{cm}^{2}$. The procedure calls for plotting ( $\mathrm{T}_{\text {cel1 }}-\mathrm{T}_{\mathrm{air}}$ ) against the irradiance level for a period when wind conditions are favorable. The NOCT. value is then determined by adding $\mathrm{T}_{\mathrm{air}}=20^{\circ} \mathrm{C}$ to the value of $\left(\mathrm{T}_{\mathrm{ce}} 11^{\left.-\mathrm{T}_{\mathrm{air}}\right)}\right.$ interpolated for the NTE irradiance level of $80 \mathrm{~mW} / \mathrm{cm}^{2}$, i.e., NOCT $=\left(\mathrm{T}_{\mathrm{ce}} 11^{-\mathrm{T}_{\mathrm{air}}}\right)$ at NTE $+20^{\circ} \mathrm{C}$.

The plot of $\left(\mathrm{T}_{\text {cel1 }}-\mathrm{T}_{\mathrm{air}}\right)$ vs $\mathrm{L}$ shall be determined by conducting a minimum of two field tests in which the module being characterized is tested under terrestrial environmental conditions approximating the NTE in accordance with the testing guidelines that follow. Each test shall include acquiring a semi-continuous record of $\left(\mathrm{T}_{\text {cel1 }}-\mathrm{T}_{\mathrm{air}}\right)$ over a one or two-day period, together with other measurements as required to characterize the terrestrial 
measurements made when the average wind velocity is $1 \mathrm{~m} / \mathrm{sec}+0.75 \mathrm{~m} / \mathrm{sec}$ and with gusts less than $4 \mathrm{~m} / \mathrm{sec}$ for a period of 10 minutes before and up to the time of measurement. Local air temperature during the test period shall not vary by more than $5^{\circ} \mathrm{C}$ and shall lie in the range of $20^{\circ} \mathrm{C}+15^{\circ} \mathrm{C}$. Using only acceptable data as defined, a plot shall be constructed from a set of measurements made either before or after solar noon that defines the relationship between $\left(\mathrm{T}_{c e 11}-\mathrm{T}_{\mathrm{air}}\right)$ and the irradiance level ( $\mathrm{L}$ ) for $\mathrm{L} \geqq 40 \mathrm{~mW} / \mathrm{cm}^{2}$.*

When $\left(\mathrm{T}_{c e 11^{-}} \mathrm{T}_{a i r}\right)$ is plotted as a function of $\mathrm{L}$ for average wind velocities less than $1.75 \mathrm{~m} / \mathrm{sec}$, results similar to those shown in Figure A-1 are obtained. For the data shown, the local air temperature was $15.6^{\circ} \mathrm{C}$ $+4.5^{\circ} \mathrm{C}$ and the wind speed varied from 0 to less than $4 \mathrm{~m} / \mathrm{sec}$ with an average of $1 \mathrm{~m} / \mathrm{sec}$. Using the plot of $\left(\mathrm{T}_{\mathrm{ce} 11^{-}} \mathrm{T}_{\mathrm{air}}\right) \mathrm{vs} \mathrm{L}$, the value of ( $\mathrm{T}_{\text {cel1 }}-\mathrm{T}_{\mathrm{air}}$ ) at NTE is determined by interpolating the average value of $\left(\mathrm{T}_{\text {cell }}-\mathrm{T}_{\mathrm{air}}\right)$ for $\mathrm{L}=80 \mathrm{~mW} / \mathrm{cm}^{2}$. Using the data in Figure $\mathrm{A}-1$ as an example, ( $\mathrm{T}_{\text {cel1 }}-\mathrm{T}_{\mathrm{air}}$ ) at NTE is determined to be $20.2^{\circ} \mathrm{C}$. The preliminary value of NOCT is thus $20.2^{\circ} \mathrm{C}+20^{\circ} \mathrm{C}=40.2^{\circ} \mathrm{C}$.

\section{Air Temperature and Wind Correction}

A correction factor to the preliminary NOCT for average air temperature and wind velocity is determined from Figure A-2. This value is added to the preliminary NOCT and corrects the data to $20^{\circ} \mathrm{C}$ and $1 \mathrm{~m} / \mathrm{sec}$. $\mathrm{T}_{\mathrm{air}}$ and $\mathrm{V}$ are the average temperature and wind velocity for the test period.

For the test data shown in Figure $A-1, \bar{V}$ is $1 \mathrm{~m} / \mathrm{sec}$ and $T_{a i r}$ is $15.6^{\circ} \mathrm{C}$. From Figure $\mathrm{A}-2$, the correction factor is $0^{\circ} \mathrm{C}$. The NOCT is therefore $40.2^{\circ} \mathrm{C}$.

\section{Test Geometry}

a. Tilt Angle. The plane of the module shall be pusiliulled su that it is normal to the sun $\left( \pm 5^{\circ}\right)$ at solar noon.

b. Height. The bottom edge of the module shall be $0.6 \mathrm{~m}$ (2 ft) or more above the local horizontal plane or ground level.

c. Panel Configuration. The module shall be situated in the interior of a planar surface that extends $2 \mathrm{ft}$ beyond the module in all directions, and that is designed to simulate the thermal boundary conditions of the expected field installation. For modules designed for free-standing, open-back installations, black aluminum plates or other modules of the same

*The effect of air temperature variation of more than $5^{\circ} \mathrm{C}$ during the test. period will appear as an increase in the scatter of plotted data, resulting in. poor correlation between the data and the resultant curve. 


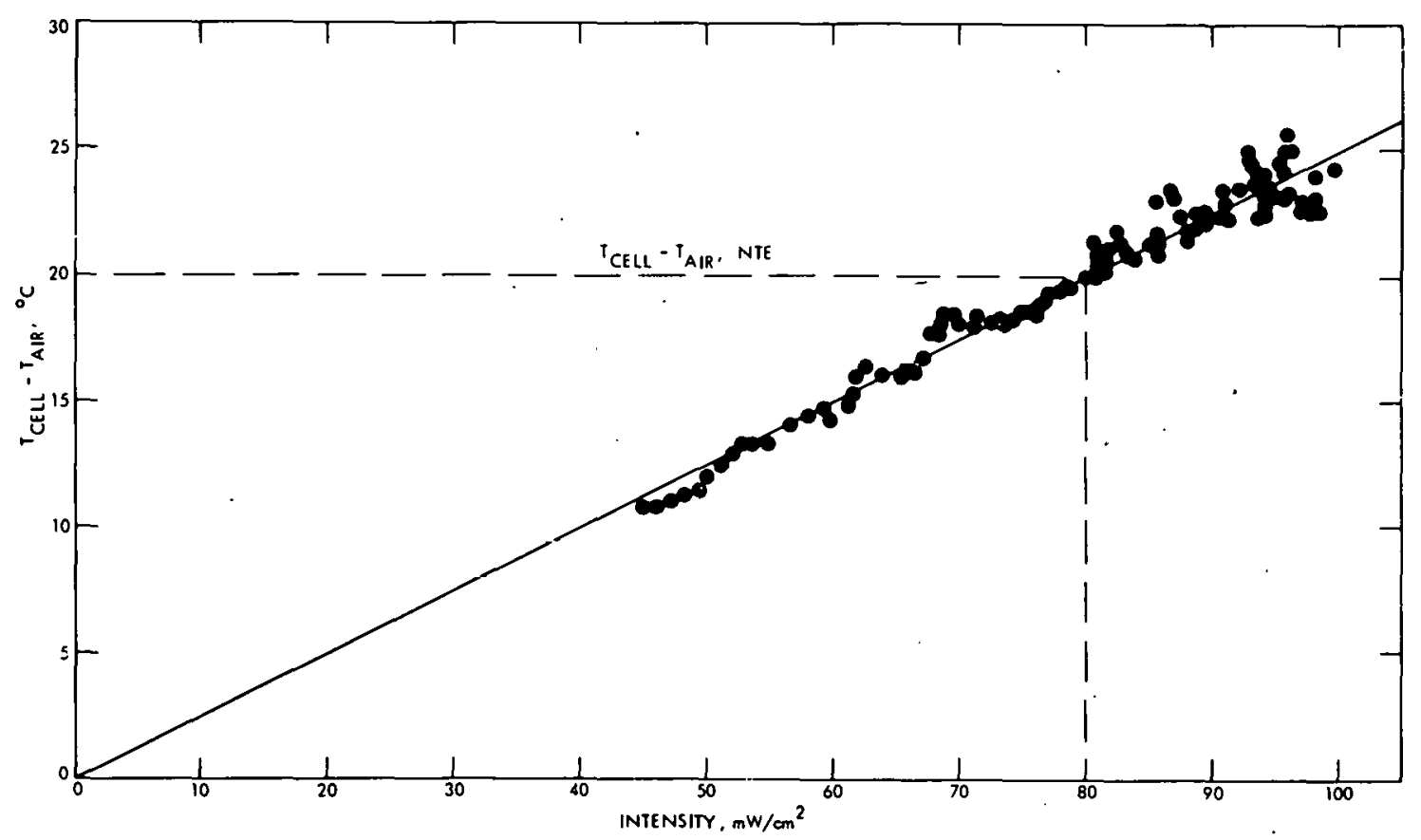

Figure A-1. Typical Cell Temperature Data

design shall be used to fill out the remaining open area of the planar surface. During testing the module should be supported in a manner that allows normal cooling of the rear surface. In the case of modules that are not self-supporting or have special mounting characteristics, the test module shall be centrally located in the planar surface and integrated with representative supporting structure and interfacing modules to simulate the thermal boundary conditions expected in field application.

d. Surrounding Area. There sha11 be no obstructions to prevent full irradiance of the module beginning a minimum of $4 \mathrm{~h}$ before solar noon and up to $4 \mathrm{~h}$ after solar noon. The ground surrounding the module shall not have an abnormally high solar reflectance and shall be flat and level, or sloping away from the test fixture in all directions. Grass, various types of ground covers, blacktop, or dirt are acceptable for the local surrounding area. Buildings or other objects having a large solar-reflective finish shall not be in the immediate vicinity. Good engineering judgment shall be exercised to ensure that both front and back sides of the module receive a minimum of reflected solar energy from the surrounding area.

e. Wind Direction. The wind shall not be predominantly from due east or due west; flow parallel to the plane of the array can result in a lower-than-typical NOCT and is not acceptable. Artificial wind generation equipment such as fans shall not be used.

f. Module Electrical Load. In order to simplify testing, data shall be obtained for a module open-circuit condition corresponding to zero electrical power output. 


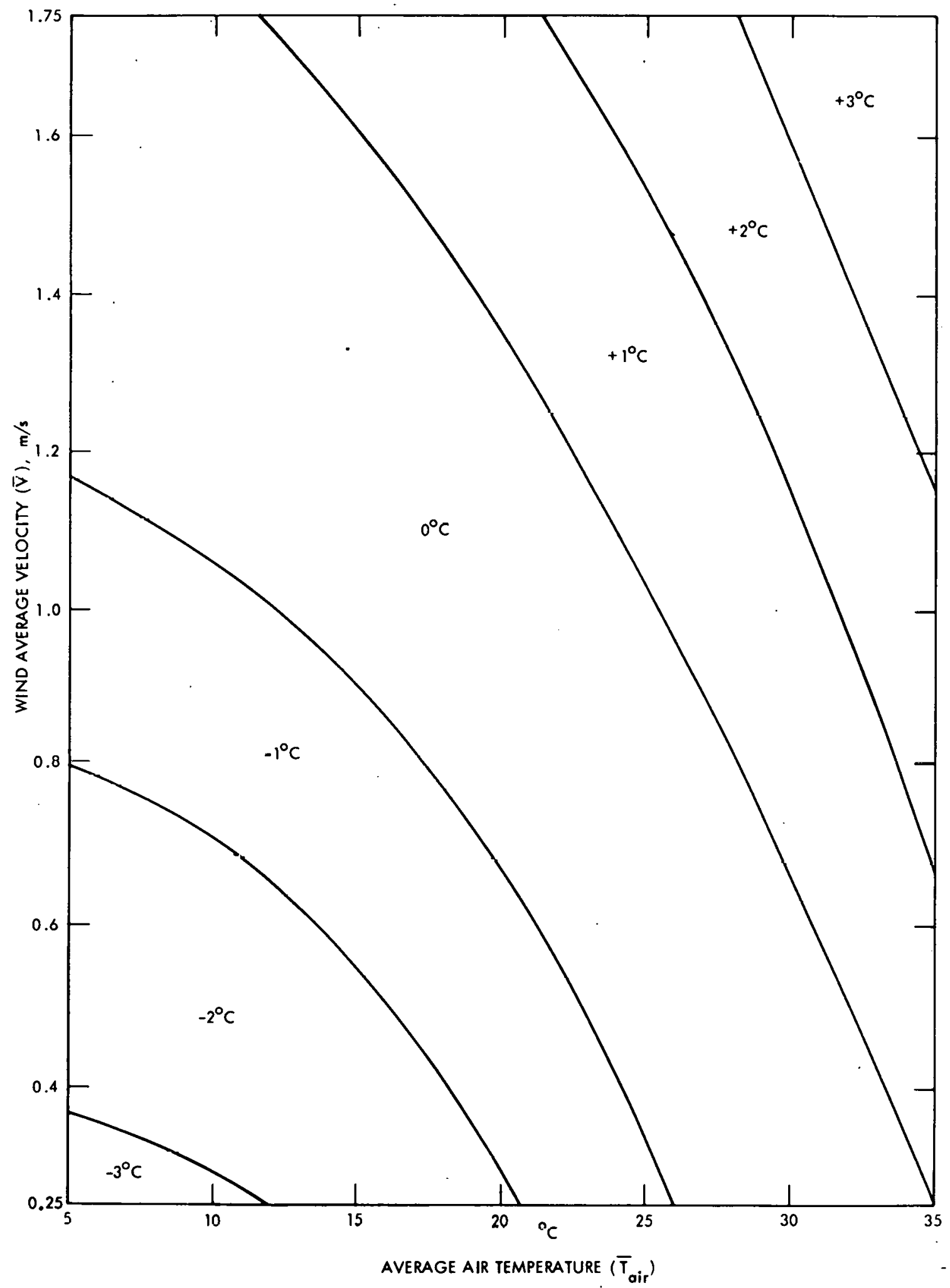

Figure A-2. NOCT Correction Factor

$$
\text { A-4 }
$$




\section{Test Equipment}

a. Pyranometer. The total solar irradiance on the active side of the module shal be measured by a pyranometer mounted on the plane of the module and within $0.3 \mathrm{~m}(1 \mathrm{ft})$ of the array. The pyranometer used shall have a traceable annual calibration to a recognized standard instrument and shall be either an Epply PSP or an equivalent Class 1 pyranometer as defined by the World Meteorological Organization.

b. Wind Measurement. Both the wind direction and wind speed shall be measured at the approximate height of the module and as near to one of the sides of the module as feasible.

c. Air Temperature. Local air temperature shall be measured at the approximate height of the module. The measurement shall be made in the shadow of the module and shall be accurate to $+1^{\circ} \mathrm{C}$. An average local air temperature is desired. This is obtained satisfactorily by increasing the thermal mass of the thermocouple by imbedding the thermocouple in a solder sphere of approximately $6 \mathrm{~mm}(0.25 \mathrm{in.}) \mathrm{dia}$. The thermocouple must be. appropriately shielded and vented.

d. Cel1 Temperature. The temperature of at least two representative interior solar cells shall be measured to $\pm 1^{\circ} \mathrm{C}$. Thermocouples shall be 36 gauge, and shall be soft-soldered directly to the back of the cells.

e. Substrate Surface Temperature. The exterior temperature of the rear of the solar module shall be measured to $+1^{\circ} \mathrm{C}$ beneath a representative cell and when practical beneath a representative space between cells. Thermocouples shall be 26 gauge, and shall be bonded down with aluminized epoxy adhesive.

\section{Data Recording}

All data shall be printed out approximately every $2 \mathrm{~min}$. In addition, solar intensity, wind speed, wind direction, and air temperature shall be continuously recorded.

\section{7. cleaning}

The active side of the solar cell module and the pyranometer bulb shall be cleaned before the start of each test. Dirt shall not be allowed to build up. Cleaning with a mild soap solution followed by a rinse with distilled water has proven to be effective.

\section{Equipment Calibration}

A calibration check shall be made of all the equipment before the start of the test and re-verified following the test. 


\section{DETERMINATION OF TEMPERATURE CORRECTION COEFFICIENTS}

\section{Purpose}

The purpose of this test is to determine the temperature correction coefficients used in transforming module electrical performance measurements made at OTC to NOC.

\section{Approach}

A photovoltaic I-V characteristic curve obtained at a given cell temperature and a fixed irradiance level can be transformed by a point-by-point correction to an $I-V$ curve at a different temperature. For purposes of translation from OTC to NOC, the irradiance is constant at $80 \mathrm{~mW} / \mathrm{cm}^{2}$. The region of the $I-V$ curve of interest is near the maximum power point. The current and voltage points on the NOC I-V curve can be obtained from the coordinates of points on the OTC I-V curve with the following equations:

$$
\begin{aligned}
& I_{\text {NOC }}=I_{\text {OTC }}+C_{I}\left(T_{N}-T_{O}\right) \\
& V_{\text {NOC }}=V_{\text {OTC }}+C_{V}\left(T_{N}-T_{0}\right)
\end{aligned}
$$

where

$$
\begin{aligned}
& \text { VOTC, IOTC are coordinates of a selected point on the curve obtained } \\
& \text { at OTC. } \\
& \mathrm{V}_{\text {NOC }}, \mathrm{I}_{\mathrm{NOC}} \text { are coordinates of the corresponding point on the NOC } \\
& \text { curve. } \\
& \mathrm{T}_{\mathrm{N}} \quad \text { is actual cell temperature, usually NOCT } \pm 2^{\circ} \mathrm{C} \text {, during } \\
& \text { the NOC curve measurement. } \\
& \text { To is actual cell temperature during the OTC curve } \\
& \text { measurement. } \\
& \mathrm{C}_{\mathrm{I}} \text { is the current-temperature coefficient, expressed as } \\
& \mathrm{A} /{ }^{\circ} \mathrm{C} \text {. } \\
& \mathrm{C}_{\mathrm{V}} \quad \text { is the voltage-temperature coefficient, expressed as } \\
& \mathrm{V} /{ }^{\circ} \mathrm{C} \text {. (usually a negative value). }
\end{aligned}
$$
production modules. 
3. Procedure

To determine $C_{I}$ and $C_{V}$, the following procedure shall be used:

(1) Install the module to be tested in a temperature-controlled environment. After stabilizing the module temperature at the cell temperature selected for oTC within $\pm 2^{\circ} \mathrm{C}$, obtain an $I-V$ curve for OTC conditions. Record the actual temperature $\left(T_{0}\right)$.

(2) Repeat Step (1) for NOC with the module stabilized at NOCT $\pm 2^{\circ} \mathrm{C}$. Record the actual temperature $\left(\mathrm{T}_{\mathrm{N}}\right)$.

(3) On the curve obtained at NOC, mark two points, near the maximum power point, and approximately equidistant from it. For reference these points should be approximately at $90 \%$ of $\mathrm{I}_{\mathrm{SC}}$ and $60 \%$ of $\mathrm{V}_{\mathrm{OC}}$.

(4) Using a light box or similar equipment, superimpose the OTC curve on the NOC curve and translate the curve rectilinearly until the curves match closely at the marked points. Mark the overlaid curve at the same points.

(5) Separate the curves and determine the voltage ( $\mathrm{V}_{\mathrm{NOC}}-$ $V_{\text {OTC }}$ ) and current $\left(I_{\text {NOC }}-I_{O T C}\right.$ ) shifts required to achieve the match.

(6) Calculate the $C_{I}$ and $C_{V}$ from the following:

$C_{I}=\frac{I_{\text {NOC }}-I_{\text {OTC }}}{T_{N}-T_{O}}$

$c_{V}=\frac{V_{\text {NOC }}-V_{\text {OTC }}}{T_{N}-T_{0}} ; C_{V}$ is usually negative.

(7) Determine the average values of $C_{I}$ and $C_{V}$ for the sample modules. 


\author{
APPENDIX C \\ HOT-SPOT ENDURANCE TEST PROCEDURE
}

\title{
1. Purpose
}

The purpose of this test procedure is to evaluate the ability of a module to endure the long-term effects of periodic hot-spot heating associated with common fault conditions such as severely cracked or mismatched cells, single-point open-circuit failures, or non-uniform illumination (partial shadowing).

\section{Commentary}

Field experience indicates that periodic circuit faults such as partial shadowing, cracking of cells, and interconnect open circuits must be expected to occur even in highly reliable arrays. Under these fault conditions it is desirable to ensure that possible hot-spot heating due to reverse biasing does not cause propagation of the fault or electrical safety hazards through such mechanisms as solder melting or encapsulant deterioration.

Hot-spot heating is caused when module operating current levels exceed the reduced short-circuit current level of an individual cell or group of cells in an array circuit. The reduced short-circuit current fault condition can be the result of a variety of causes including non-uniform illumination (local shadowing), individual cell degradation due to cracking or soiling, or loss of a portion of a series-parallel circuit due to individual interconnect open circuits. Under this condition the cell(s) carrying the excess current dissipate power equal to the product of the current and the reversed voltage that develops across the cell(s), which can heat the cell(s) to elevated temperatures.

\section{Test Procedure}

The preferred procedure for conducting this test includes a series of steps, first to select and instrument appropriate cells for testing, then to determine the hot-spot test levels, and last to conduct the hot-spot endurance test.

a. Cell selection and Instrumentation. The degree of hot-spot heating within an affected cell is dependent on a variety of conditions, including the module series-paralleling, the amount of overall illumination, the amount of over-current in the affected cell, and the reverse-voltage I-V characteristics of the affected cell(s). Because the reverse-voltage I-V characteristics vary considerably from cell to cell within a given module, it is necessary first to determine the dark reverse-voltage $I-V$ curve for a representative sample of cells (at least 10) within the test module. This can be done by directly accessing individual cells or by obtaining data for 
multiple points using the shadow technique.* The cell's dark characteristics should be determined for reverse voltages from 0 to $v_{L}$ or currents from 0 to $I_{L}$, whichever 1 imit is reached first, where:

$$
\begin{aligned}
I_{L}= & I_{S C} \text { of an average cell at } 100 \mathrm{~mW} / \mathrm{cm}^{2}, \text { NOCT. } \\
V_{L}= & N \times V_{m p} \text { of an average cell at } 100 \mathrm{~mW} / \mathrm{cm}^{2}, \text { NOCT. } \\
N= & \text { Number of series cells per bypass diode or number of series cells } \\
& \text { per module, whichever is less. }
\end{aligned}
$$

When the family of reverse-voltage $I-V$ curves is plotted for the representative sample of cells, a graph similar to Figure C-1 should be obtained. The individual curves may be either all voltage-limited (Type A), current-limited (Type B), or a combination of both (as shown). In general, the cells associated with the highest hot-spot heating levels are those with the highest shunt resistance, although low shunt resistance may be associated with highly localized heating.

For testing, select three non-adjacent individual cells within the test module from the measured sample: one representative of the highest shunt resistance obtained, one representative of the average, and one representative of the lowest. Provide the test cells with positive and negative electrical leads to allow them to be connected individually to separate power supplies. Eliminate parallel current paths around the selected test cells by disrupting cell-to-cell connections as necessary. The lead attachment should minimize disruption of the cell's heat-transfer characteristics or the hot-spot endurance of the encapsulant system.

b. Selection of Hot-Spot Test Leve1. The objective of this portion of the test procedure is to select the level of heating and the corresponding test condition that will stress the module in a manner similar to a severe hot-spot field condition. The severity of the field condition will depend on the array circuit configuration, the array I-V operating point, the ambient thermal conditions, the overall irradiance level, and the previously described characteristics of the affected cells. In particular, whether the cells are Type A or Type B is important.

For Type A Cells. The maximum cell reverse voltage $\left(V_{L}\right)$, the cell illumination level, and the ambient thermal environment are the key parameters. When a module is incorporated into an array branch circuit the maximum reverse voltage imposed on an individual cell can approach the maximum array operating voltage. In this procedure it is assumed that the array

*See Hoffman, A.R., and Miller, E.L., Bias-Humidity Testing of Solar Cell Modules, JPL Publication No. 5105-84, 0ct. 15, 1978. 


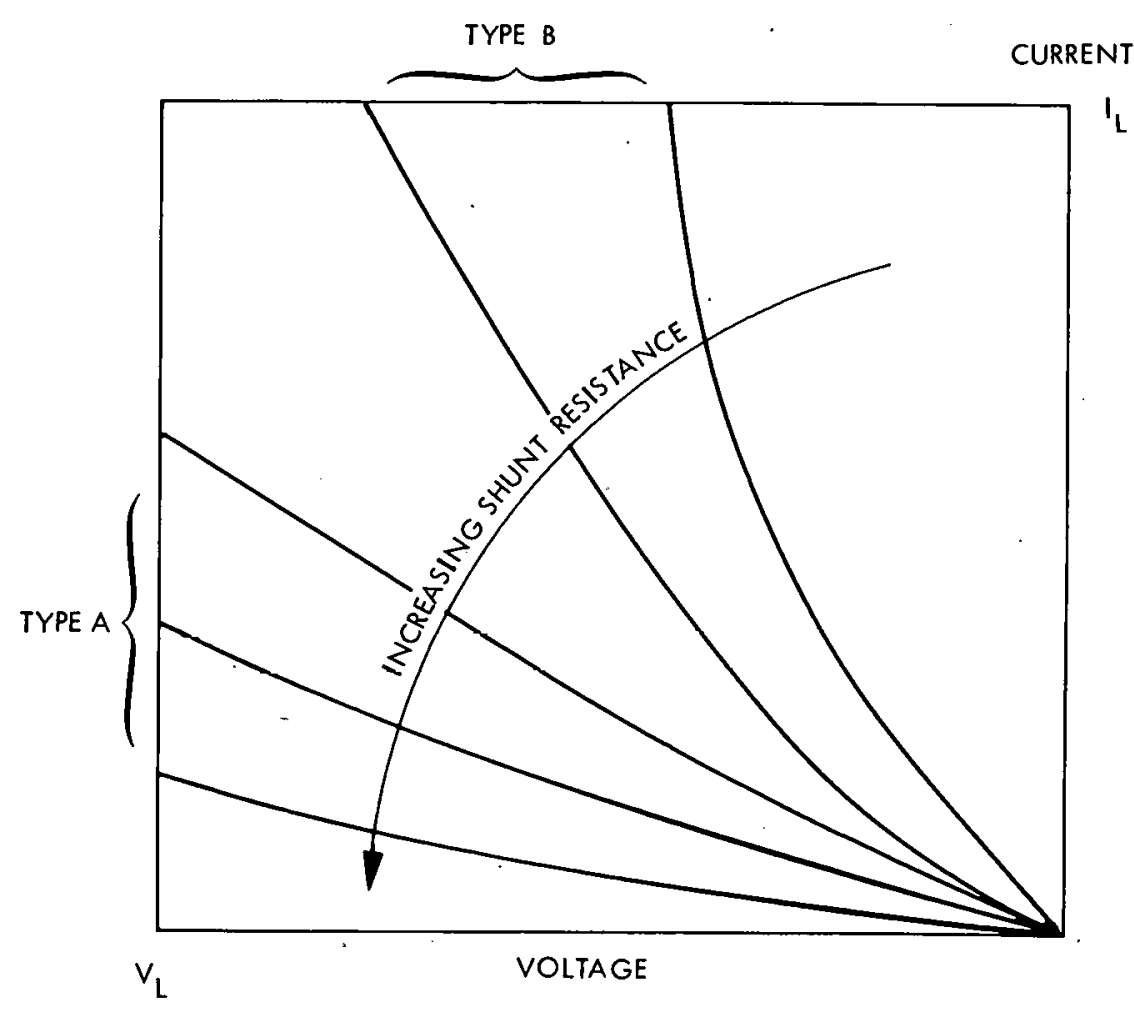

Figure C-1. Typical Reverse-Voltage I-V Plot for a Sample of Ce11s

designer has used bypass diodes or other means to limit the reverse voltage on any single module to less than one volt. The test voltage $\left(v_{\text {test }}\right)$ is thus set to yield the maximum reverse voltage that can be applied across a single cell when the test module is shorted with a bypass diode. For type A cells, $V_{\text {test }}$ shall be set equal to $N$ times the average $V_{m p}$ of an individual cell, where $\mathrm{N}$ is the number of series cells per bypass diode, or the number of series cells per module, whichever is less.

The second key test condition for Type A cells is the illumination level; it directly controls the hot-spot test current ( $I_{\text {test }}$ ) level, and therefore the power level. As shown in Figure $\mathrm{C}-2$, there is a unique illumination level that corresponds to worst-case power dissipation for any particular Type A solar cell. In the test, the irradiance level on the test cell shall be adjusted to achieve this worst-case condition with $I_{\text {test }}$ set equal to the average cell maximum power current at $100 \mathrm{~mW} / \mathrm{cm}^{2}$, NOCT.

The third test condition is the level of the ambient thermal environment. For test purposes a nominal terrestrial environment shall be created by using an air temperature of $20^{\circ}+5^{\circ} \mathrm{C}$ and a radiant heating source to achieve a uniform background moduTe cell temperature equal to NOCT.

Type B Cells. Type B cells have a cell shunt resistance so low that the maximum reverse test voltage $\left(V_{\text {test }}\right.$ ) is set by the $I-R$ drop across the cell associated with the available current level. In these cells, worst-case heating occurs when the test cell is totally shadowed, and the current level is at a maximum. Test conditions for Type B cells shall therefore maintain a cell illumination level of 1 ess than $5 \mathrm{~mW} / \mathrm{cm}^{2}$ (to allow 


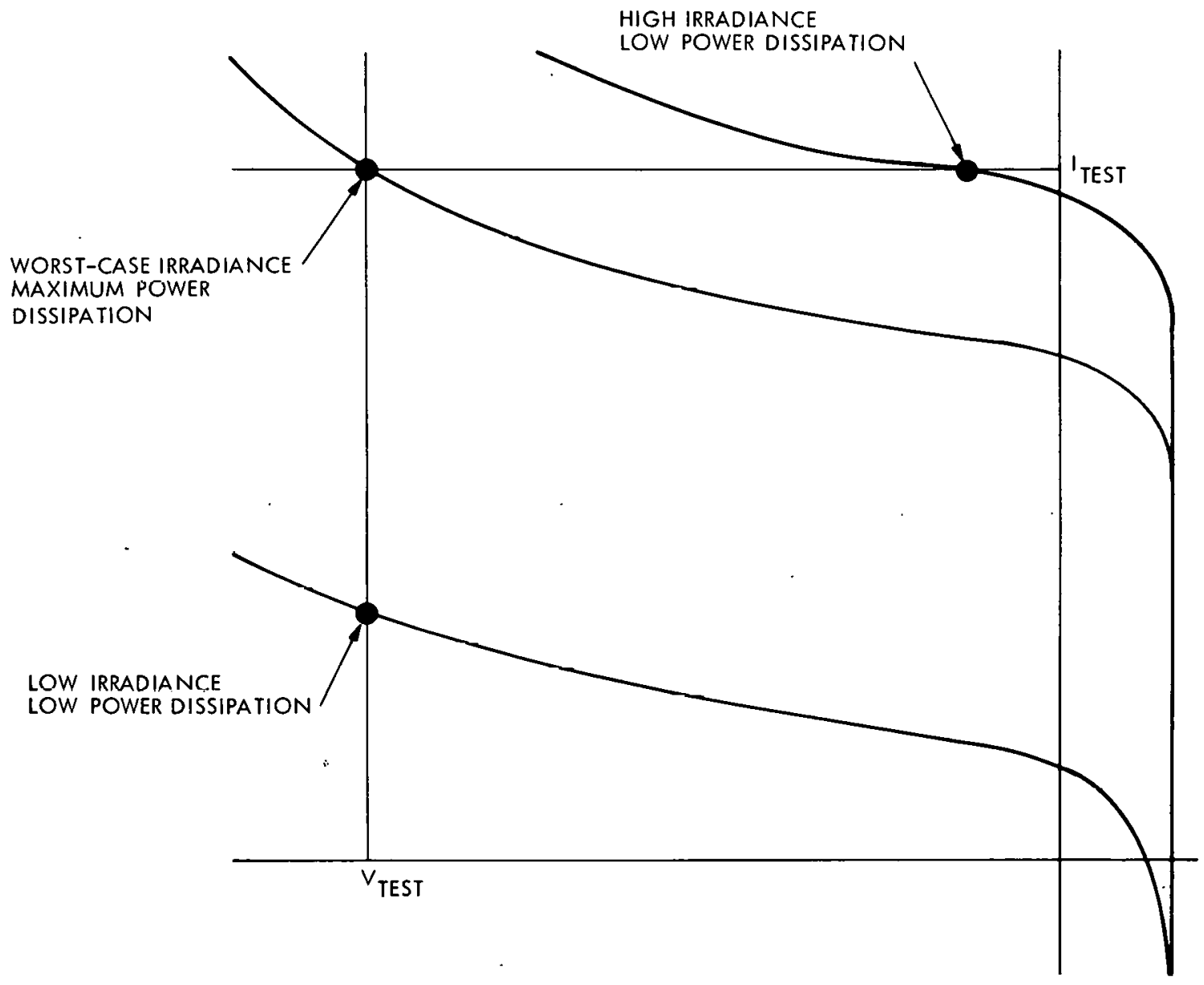

Figure C-2. Effect of Test-Cell Illumination Level on Hot-Spot Power Dissipation

for room lighting and an IR heating source) and a current test level ( $I_{\text {test }}$ ) equal to the short-circuit current of an average cell at $100 \mathrm{~mW} / \mathrm{cm}^{2}$, NOCT.

As with type A cells, a uniform background cell temperature equal to. NOCT $+2^{\circ} \mathrm{C}$ shall be created by using an air temperature of $20^{\circ} \pm 5^{\circ} \mathrm{C}$, together with a radiant heating source.

c. Test Execution. Detailed steps for execution of the test involves subjecting the three selected test cells to cyclic hot-spot heating, at the levels determined above, for a period of $100 \mathrm{~h}$ total on-time, are as follows :

(1) Connect a separate dual limiting constant-current constant-voltage power supply to each test cell with polarity arranged to drive the cells with reverse voltage. Adjust the voltage and current limits to the $V_{\text {test }}$ and $I_{\text {test }}$ values determined in Step $b$ above. 
(2) Apply an IR radiant-heating source with a visible light contribution below $5 \mathrm{~mW} / \mathrm{cm}^{2}$ to the module front surface and adjust the heating level to achieve a uniform module cell temperature equal to NOCT $+2{ }^{\circ} \mathrm{C}$. The ambient air should be still and at a temperature of $20^{\circ} \pm 5^{\circ} \mathrm{C}$.

(3) For Type A cells only, arrange an additional light source to illuminate each test cell to the unique level determined in Step $b$ (Figure $\mathrm{C}-2$ ). This is most easily accomplished after the power supply and IR source are turned on by adjusting the illumination level to achieve, simultaneously, both current and voltage limiting at $I_{\text {test }}$ and $V_{\text {test }}$ after equilibrium test conditions stabilize. The illumination source should not contain excessive infrared or ultraviolet irradiance that would lead to abnormal heating or accelerated UV aging. ELH type tungsten sources have been found to meet this requirement.

(4) Connect the power supplies, IR source, and 1 ight sources to an appropriate timer to obtain a cyclic on-off operation with an on-time equal to $1 \mathrm{~h}$, and an off-time sufficient to allow the test cells to cool to within $10^{\circ} \mathrm{C}$ of the ambient air temperature.

(5) Conduct the test until a total of $100 \mathrm{~h}$ of on-time has been accumulated.

(6) Visually inspect the test cells and adjacent areas of the encapsulation system at approximately 24-h intervals during the test while under bias conditions, and upon completion of the 100-h sequence. Identify any evidence of degradation, including delamination, outgassing or blistering of encapsulants, cell cracking, solder melting or other defects as defined by the JPL-approved visual inspection criteria (Section III, Part B, Paragraph 6) resulting from this test. Measure the post-test electrical performance of the module for comparison with baseline electrical performance per Section IV, Part A. Perform a post-test electrical isolation test in accordance with Section III, Part B, Paragraph 4. 